\title{
A Review: Using Marigolds (Tagetes spp.) as an Alternative to Chemical Nematicides for Nematode Management
}

\author{
Mehmet Karakas ${ }^{1}$, Ekrem Bolukbasi*2,3
}

\author{
${ }^{1}$ Science Faculty, Department of Biology, Ankara University, Ankara, TURKEY \\ ${ }^{2}$ Suluova Vocational School, Department of Environmental Protection and Technologies, Amasya University, Amasya, TURKEY \\ ${ }^{3}$ Central Research Laboratory, Amasya University, Amasya, TURKEY \\ E-mail: ekrem.bolukbasi@amasya.edu.tr
}

\begin{abstract}
Most plant parasitic nematode management methods are pre-plant treatments. One such treatment is the planting of cover crops that can reduce nematode populations. A cover crop is a crop that is grown before the main cash crop is planted. This method is used to either avoid soil erosion caused by fallowing land, or to reduce a pest that cannot reproduce on the cover crop for various reasons. Some cover crops release substances that are able to suppress other organisms. This is called allelopathy. Marigold (Tagetes spp.) which is a popular bedding plant, can be used as such a cover crop. The root exudates of marigold known to contain toxic bioactive chemicals having nematicidal, insecticidal, fungicidal, antiviral and cytotoxic activities. Thus as a method of biocontrol of plant parasitic nematodes, growing of marigolds is not only a comely but also highly economical and helps in environmental amelioration.
\end{abstract}

Keywords—Nematode management, Biocontrol, Marigold, Tagetes spp.

\section{BACKGROUND}

Plant-parasitic nematodes are recognized as one of the greatest threat to crops throughout the world. Nematodes alone or in combination with other soil microorganisms have been found to attack almost every part of the plant including roots, leaves, fruits and seeds. The primary soilborne plant-parasitic nematodes impacting cropping systems are the root-knot, reniform, cyst, burrowing, stem and bulb, seed gall, lance, spiral, ring, dagger, stubby root, needle, bud and leaf, and lesion nematodes, all of which contain spear-like mouthparts (stylet) used to puncture plant roots and obtain nutrients. Plant-parasitic nematodes can seriously damage or even kill crops, turf, and ornamental plants. They are difficult to control because they live underground or inside the plants. While some nematicides are available for use in commercial agriculture, there are no nematicides available for homegardners [1-3].

As a result of, these nematodes cause significant economic damage to a wide variety of crops. After crops are infected with nematodes, crop yield and quality are reduced, either directly from root deformation caused by nematode feeding or indirectly from predisposition to infection by other pathogens that results from nematode penetration into the roots. The methods most frequently used for managing nematodes in agriculture include rotating crops with plants that are not host of plant-parasitic nematodes, using resistant plants if available, and applying chemical nematicides. Additional methods include soil solarisation, and the use of organic amendments, microbial biocontrol agents, and plants that are antagonistic to plant-parasitic nematodes $[4,5]$.

This review focuses on the latter alternative, and specifically discusses the potential use of marigold (Tagetesspp.) plants for managing plant-parasitic nematodes.

\section{MARIGOLD (Tagetes spp.) as EFFECTIVE NEMATODE SUPPRESSING CROP}

Therefore, most nematode management strategies are preplant treatments. One such treatment is the planting of cover crops that can reduce nematode populations. A cover crop is a crop that is grown before the main cash crop is planting. This practice is used to either avoid soil erosion caused by fallowing land, or to reduce a pest that cannot reproduce on the cover crop for various reasons. Some cover crops release substances that are able to suppress other organisms. This is called allelopathy. Marigold (Tagetes spp.) plants suppress plant parasitic nematodes through the process of biochemical interaction known as Allelopathy, which is defined as the release of compounds from plants that are toxic to other plants, micro-organisms 
or other organisms such as nematodes. Marigold plants produce a number of potentially bioactive compounds among which alpha-therthienyl is recognized as one of the most toxic chemical. The sulphur-containing bioactice compound is abundant in marigold tissues, including roots. The nematicidal activity of marigold has been detected in roots of growing plants but not in roots or leaf extracts. That's why marigold which is a popular bedding plant, can be used as such a cover crop. It has insecticidal, fungicidal, nematicidal, antiviral, and cytotoxic activities, and is believed to be the main compound responsible for the nematicidal activity of marigold. Thus nematodes may be killed either by entering the root system of a marigold plant or contacting soil containing marigold's bioactive compounds [6-8].

Marigold had been reported to contain 5-(3-buten-1-enyl)2,2-bithienyl and alpha terthienyl in a synthetic form and acts as nematode suppressant. The roots of marigold was reported to contain flavonoids, Di-hydroflavonoid, flavones and flavonones lacking a free - $\mathrm{OH}$ group. The roots had also been reported to contain chemicals like amines, amides, phenols and ketones [9].

It has been reported that alpha terthienyl was a major bioactive compound secreted by marigold roots. These types of compounds along with bithienyl compounds from aerial parts of Tagetesspecies are extremely bioactive in nature. More recently El-Gengaihi et al., (2001) isolated three nematicidal compounds using chloroform from Tageteserecta, Tagetespatula and Tagetesminuta [10]. These compounds included 5(-ent-1-ol)-2,2-bithienyl, sigma-4, 22-dien-3-beta-ol, and 5-(4-acetoxy-1-butenyl)2,2-bithienyl. Alpha terhienyl is a heterocyclic sulphur containing usually abundant in Tagetestissue. Biological activity is greatly enhanced by photo-activation with the near UV light, resulting in the production of singlet active oxygen molecule which is biocidal in nature [11].

African (Tageteserecta), French (Tagetespatula) and Mexican (Tagetesminuta) marigolds are the most commonly used species of these plants. Each consists of varieties that differ in characteristics such as colour, bloom size, shape as well as plant size and leaf shape. Marigolds are typically grown for ornamental purposes as bedding plants, studies have found that they can be highly toxic to plant parasitic nematodes and are capable of suppressing a wide range of nematode pests (Table 1). Marigold can suppress 14 genera of plant parasitic nematodes, with lesion nematodes (Pratylenchusspp.) and root-knot nematodes (Meloidogyne spp.) the most affected. Different varieties of marigolds vary in their ability to suppress nematodes. In addition, nematode suppression is influenced by crop plants, nematode species and soil temperature [12].

\section{MODE OF ACTION}

Marigold may reduce plant-parasitic nematode populations by several means, including acting as a non-host or poor host, producing allelopathic compounds that are toxic or inhibit plant-parasitic nematode development, creating an environment that favours nematode antagonistic flora or fauna [13] or behaving as a trap crop [14]. These mechanisms may occur separately or in combination resulting in lower plant parasitic nematode numbers [15]. The nematicidal activity of marigold has been detected in roots of growing plants but not in root or leaf extracts. Some studies have shown that these nematicidal properties result from a sequence of events in the marigold roots triggered by penetration and movement of nematodes through the root tissue, and the end product of these reactions is thought to kill nematodes. Nematicidal compounds apparently permeate from marigolds' root tissues into nematodes attached to the root, but they are also believed to kill nematodes found in the rhizosphere, the soil near marigold roots. Thus, marigold is believed to be most effective in suppressing plant parasitic nematodes when actively growing, but it is not as effective when incorporated as crop residues or root extracts [16].

Some researchers believe that marigold root exudates prevent the nematodes from developing and their eggs from hatching. However, the nematode species and growth stages suppressed by marigold vary with the marigold species. For example, T. patula var. Single Goldis an extremely poor host of the root-knot nematode, and there is limited penetration and development by this nematode on this plant. However, another marigold species, T. erecta var. Cracer Jack, behaved as a trap crop [8].

\section{HOST STATUS}

It is critically important to know which nematode species is responsible for crop damage before selecting a marigold plant. The bioactive compounds of different marigold species and cultivars may differ in composition, quality and quantity. Thus, certain species may be highly effective against one nematode species but have limited to no impact on or possibly increase populations of other plant parasitic nematodes. Tagetespatula 'Single Gold', T. hybrid 'Polynema', and T.erecta 'Cracker Jack' effectively suppressed four root-knot nematode species: Meloidogynearenaria, M. incognita, M. javanica and $M$. hapla. Marigolds 'Polynema' and 'Cracker Jack' are good hosts for reniform nematodes but that marigold $T$. patula ${ }^{\circ}$ Boy-O-Boy' supressesreniform nematode 
populations [16].Reniform and root-knot nematodes are commonly found infesting agricultural field, therefore, marigold 'Single Gold' is recommended for use in fields containing populations of both these nematodes. Field experiments showed that growing marigold 'Single Gold' consistently suppressed root-knot nematode and consequently, lowered root galling of tomato grown over several subsequent seasons and increased tomato yield by about 50 percent (Table 1). Researchers found that $T$. patula was the most effective cover crop for improving taro (Colocastiaesculenta) yields among 22 cover crops tested in fields infested with M. javanica [10].
The marigold $T$. patula alsosupresses lesion nematodes Pratylenchuspenetrans and $P$. pratensis, which are parasites of ornamentals, coffee, and other important crops [7, 17].Tageteserecta lowered levels of burrowing (Radopholussimilis), spiral (Helicotylenchusmulticinctus), and lance (Hoplolaimusindicus) nematodes when intercropped with a highly susceptible banana crop. Tageteserecta produces more biomass than several cultivars of $T$. patula and thus establishes well in the field, making it ideal for use as a cover crop. However, T. patula 'Single Gold' can also generate a significant amount of biomass, similar to T. erecta 'Cracker Jack' and thus may be an ideal marigold cover crop [18].

Table 1 Susceptibility of several marigold species/variety to some commonly occurring plant-parasitic nematodes

\begin{tabular}{|c|c|c|c|c|c|c|c|c|}
\hline \multirow[b]{2}{*}{ Marigold species/variety } & \multicolumn{8}{|c|}{$\underline{\text { Nematode Groups }}$} \\
\hline & Awl & Burrowing & Lance & Lesion & Reniform & $\begin{array}{l}\text { Root- } \\
\text { knot }\end{array}$ & Sting & $\begin{array}{c}\text { Stubby- } \\
\text { root }\end{array}$ \\
\hline Tageteserecta & - & $\mathrm{R}$ & - & - & $\mathrm{R}$ & - & - & - \\
\hline T. erecta'Cracker Jack' & - & - & - & $\mathrm{R}$ & $\mathrm{S}$ & $\mathrm{R}$ & - & - \\
\hline Tagetesminuta & - & - & - & - & - & $\mathrm{R}$ & - & - \\
\hline Tagetespatula & S & - & I & $\mathrm{R}$ & $\mathrm{R}$ & - & S & S \\
\hline T. patula 'Single Gold' & - & - & - & - & - & $\mathrm{R}$ & - & - \\
\hline T. patula 'Boy-O-Boy' & - & - & - & - & $\mathrm{R}$ & - & - & - \\
\hline Tageteshybrid 'Polynema' & - & - & - & - & $\mathrm{S}$ & $\mathrm{R}$ & - & - \\
\hline Tagetessignata & - & - & - & - & - & $\mathrm{R}$ & - & - \\
\hline
\end{tabular}

S: Susceptible, R: Resistant, I: Intermediate, -: Undetermined

\section{V.}

\section{MARIGOLD AS A HOST PLANT}

Researches showed that some plant parasitic nematodes are not adversely affected by marigold and may even use it as a host plant. Lehman (1979) found that an unknown species of Tageteswas a suitable host for ring nematode (Criconemoidesmutabile), stubby-root nematode (Paratrichodorusteres), sheath nematode (Hemicycliophorasimilis), reniform nematode (Rotylenchulusrobustus) and pin nematodes (Paratylenchus sp.) [19]. At the same time Wang et al. (2003) reported that $T$. erecta was a suitable host for reniform nematode, Rotylenchulusreniformis [20]. With the exception of reniform nematode, all of these feed mainly as ectoparasitic nematodes. In another study, McSorley et al. (2009) reported that the number of spiral nematode (Helicotylenchusdihystera), an ectoparasitic nematode increased over time on T. patula [21].
5.1 Rules of marigold use

It is important to know that alpha-therthienyl compound in marigold have limited nematicidal activity when incorporated into the soil.Only living marigold root systems exhibit significant nematicidal properties. The nematicidal activity of marigold has been detected in roots of growing plants but not in root of leaf extracts. For example, even though a $T$. patula 'Single Gold' crop consistently supressed a diverse range of plant parasitic nematodes, when residues were incorporated into the soil it did not supress the root-knot nematode as well. The critical stage for marigold suppressive effect is during its growth. Marigold are typically grown as a cover crop or planted in rotation with the cash crop manage nematodes. For example, intercropping banana with marigolds 'Cracker Jack' and 'Single Gold' reduced population densities of Meloidogyne, Radopholus, Rotylenchulus, and Pratylenchusnematodes and reduced banana root damage. In another study, intercropping sugarcane with $T$. erecta 
reduced population densities of spiral nematodes and increased sugarcane yield and quality[22-25].

5.2 Marigold nematicidal activity and non-target organisms

Marigold root extracts were found to have no suppressive effect on several other soil microorganisms. Further, although incorporating marigold residues into the soil does not enhance the nematicidal effect, it may enhance propagules of nematophagous fungi that adhere to or prey on nematodes[26-28].

\subsection{Marigold nematicidal activity and temperature}

Temperature is an important factor for nematode suppression by marigold. For example, marigold 'Single Gold', T. patula 'Tangerine', and T. erecta 'Flor de Muerto' supressed root-knot nematode infection on subsequent tomato plants compared to a fallow treatment at 20-30 ${ }^{\circ} \mathrm{C}$. However, T. signata'Tangerine Gem' and $T$. hybrid 'Polynema' failed to suppress $M$. incognita at temperatures higher than $30^{\circ} \mathrm{C}$. Tageteserecta 'Cracker Jack' only reduced $M$. incognita densities at temperatures ranging from 10 to $30^{\circ} \mathrm{C}$ [12].

\section{CONCLUSION}

As registered chemical formulated insecticides for nematodes continue to become more limited in availability, it will be necessary to develop other management strategies for plant parasitic nematodes. In generally, synthetic nematicides are expensive and because of their toxicity have adverse effects on non-target organisms, such as beneficial soil microorganisms. The negative aspects of soil fumigants and nematicides and the increasing demand for organic produce and less environmentally harmful agricultural practices make marigold a potentially valuable alternative to chemical nematicides for nematode management.

It is clear that marigold can be used as a substitute for synthetic nematicides. In some instances, marigold can reduce nematode populations at greater soil depths than soil fumigation. In addition, marigold is more environmentally friendly than chemical nematicides because it does not repress other soil microorganisms. However, to successfully incorporate marigold into an integrated nematode management program it is important to select a marigold variety that is effective against the locally occurring nematode populations.

As a result of that to optimize their use in integrated pest management programs, cover crops should not be used solely to mitigate problems caused by plant parasitic nematodes, but rather used simultaneously to help suppress multiple pest organisms and provide other benefits to a farming operation.

\section{REFERENCES}

[1] Zuckerman, B.M., Mai, W.F., Rohde, R.A. (1971). Plant Parasitic Nematodes, Vol. 1. Morphology, Anatomy, Taxonomy and Ecology. Academic Press, New York, U.S.A, 360 pp.

[2] Baldwin, J.G. and Perry, R.N. (2004). Nematode morphology, sensory structure and function. Nematology, Advances and Perspectives. Vol: I, Ed. Chen ZX, Chen SY, Dickson DW. CABI Publishing, Tsinghua University Press. London, UK pp. 175-236.

[3] Perry, R.N. and Moens, M. (2006). Plant Nematology. CABI London Printed by Biddles Ltd. King's Lynn, 447p.

[4] Yeates, G.W. and Boag, B. (2004). Background for nematode ecology in the 21 st Century. Nematology, Advances and Perspectives. Vol: I, Ed. Chen ZX, Chen SY, Dickson DW. CABI Publishing, Tsinghua University Press. London, UK pp. 406-437.

[5] Bird, A.F. (2004). Surface Adhesion to nematodes and its consequences. Nematology, Advances and Perspectives. Vol: 1. Ed. Chen ZX, Chen SY, Dickson DW. CABI Publishing, Tsinghua University Press. London, UK pp. 295-321.

[6] Suatmadji, R.W. (1969). Studies on the effect of Tagetes species on plant parasitic nematodes. H. Veenman en Zonen, Wageningen, The Netherlands $132 \mathrm{pp}$.

[7] Pudasaini, M.P., Viaene, N. and Moens, M. (2006). Effect of marigold (Tagetes patula) on population dynamics of Pratylenchuspenetrans, in a field. Nematology 8: 477-484.

[8] Wang, K-H., Hooks, C.R.R. and Ploeg, A. (2007). Protecting crops from nematode pests: Using marigold as an alternative to chemical nematicides. Cooperative Extension Service, College of Tropical Agriculture and Human Resources 1-6.

[9] Wells, C., Bertsch, W. and Perich, M. (1992). Isolation of volatiles with insecticidal properties from the genus Tagetes (Marigold). Chromatographia 34: 241-248.

[10] El-Gengaihi, S.E., Osman, H.A., Youssef, M.M.A. and Mohamed, S.M. (2001). Efficacy of Tagetes species extracts on the mortality of the reniform nematode, Rotylenchusreniformis. Bull NRC, Egypt 26: 441-450.

[11] Bhattacharyya, M. (2017). Use of marigold (Tagetes sp.) for the successful control of nematodes in agriculture. The Pharma Innovation Journal 6(11): 1-3.

[12] Ploeg, A.T. and Maris, P.C. (1999). Effect of temperature on suppression of Meloidogyne incognita by Tagetes cultivars. Journal of Nematology 31(4): 709-714.

[13] Wang, K-H., Sipes, B.S. and Schmitt, D.P. (2001). Suppression of Rotylenchulusreniformis by Crotalaria juncea, Brassica napus, and Tageteserecta. Nematropica 31(2): 235-249.

[14] Pudasaini, M.P., Viaene, N. and Moens, M. (2008). Hatching of the root-lesion nematode, Pratylenchuspenetrans, under the influence of temperature and host. Nematology 10: 47-54. 
[15] Hooks, C.R.R., Wang, K-H., Ploeg, A. and McSorley, R. (2010). Using marigold (Tagetes spp.) as a cover crop to protect crops from plant-parasitic nematodes. Applied Soil Ecology 46: 307-320.

[16] Natarajan, N., Cork, A., Boomathi, N., Pandi, R., Velavan, S. and Dhakshnamoorthy, G. (2006). Cold aqueous extracts of African marigold, Tageteserecta, for control of tomato root knot nematode, Meloidogyne incognita. Crop Protection 25: 1210-1213.

[17] Evenhuis, A., Korthals, G.W. and Molendjik, L.P.G. (2004). Tagetes petula as an effective catch crop for longterm control of Pratylenchuspenetrans. Nematology 6(6): 877-881.

[18] Alexander, S.A. and Waldenmaier, C.M. (2002). Suppression of Pratylenchuspenetrans populations in potato and tomato using African marigolds. Journal of Nematology 34: 130-134.

[19] Lehman, P.S. (1979). Factors influencing nematode control with marigols. Fla. Dept. Agric and Consumer Services. Division of Plant Industry. Nematology Circular 50, 2 pp.

[20] Wang, K-H., Sipes, B.S. and Schmitt, D.P. (2003). Intercropping cover crops with pineapple for the management of Rotylenchulusreniformis and Meloidogynejavanica. Journal of Nematology 35: 30-47.

[21] McSorley, R., Seal, D.R., Klassen, W., Wang, K-H. and Hooks, C.R.R. (2009). Non-target effects of sunn hemp and marigold cover crops on the soil invertebrate community. Nematropica 39: 235-245.

[22] Siddiqui, M.A. and Alam, M.M. (1987a). Control of plant parasitic nematodes by intercropping with Tagetesminuta. Nematology Mediterranean 15: 205-211.

[23] Siddiqui, M.A. and Alam, M.M. (1987b). Utilization of marigold plant wastes for the control of plant parasitic nematodes. Biological Wastes 21: 221-229.

[24] Sipes, B.S. and Arakaki, A.S. (1997). Root-knot nematode management in dry land taro with tropical cover crops. Supplied Journal of Nematology 29: 721-724.

[25] Ploeg, A.T. (2002). Effect of selected marigold varieties on root-knot nematodes and tomato and melon yields. Plant Disease 86: 505-508.

[26] Topp, E., Millar, S., Bork, H. and Welsh, M. (1998). Effect of marigold (Tagetes sp.) roots on soil microorganisms. Biological Fertilization of Soils 27: 149-154.

[27] Karakas, M. and Bolukbasi, E. (2017). Bio-insecticide effect of black cumin against Granary weevil, Sitophilus granarius L. (Coleoptera: Curculionidae) on stored wheat. International Journal of Entomology Research 2(4): 38-40.

[28] Wang, K-H., McSorley, R., Gallaher, R.N. and KokalisBurelle, N. (2008). Cover crops and organic mulches for nematode, weed and plant health management. Nematology 10: 231-242. 